\title{
A Literature Review on Extraction of Potable Water from Atmospheric Air Using Solar Stills: Recent Developments
}

\author{
Merdin Danışmaz ${ }^{1 *}$, Mohammed Alhurmuzi ${ }^{2}$ \\ 1* Ahi Evran University, Faculty of Engineering Architecture, Departmant of Mechanical Engineering, Kırşehir, Turkey, (ORCID: 0000-0003-2077-9237), \\ m.danismaz@ahievran.edu.tr \\ 2 Ahi Evran University, Faculty of Engineering Architecture, Departmant of Mechanical Engineering, Kurşehir, Turkey, (ORCID: 0000-0002-7045-4628), \\ mhurmuzlu94@gmail.com
}

(International Conference on Design, Research and Development (RDCONF) 2021 - 15-18 December 2021)

(DOI: 10.31590/ejosat.1039866)

ATIF/REFERENCE: Danismaz, M. \& Alhurmuzi, M. (2021). A Literature Review on Extraction of Potable Water from Atmospheric Air Using Solar Stills: Recent Developments. European Journal of Science and Technology, (32), 991-999.

\begin{abstract}
Drinking water and utility water are indispensable elements in meeting many vital needs, especially drinking, cooking and cleaning. Unconscious agricultural irrigation, pollution, and population growth cause water scarcity that humanity must cope with. As a result of global warming and climate change, especially the amount of potable water is decreasing, making it difficult to access clean water resources. The occupancy of drinking water sources decreases in high temperature seasons and some of them even disappear. This situation has made it necessary to search for alternative methods to obtain drinking water. One of these methods is to obtain potable water from atmospheric air containing high amounts of water. With the widespread use of this method, the scarcity of drinking water can be alleviated to a certain extent. In this study, the processes of condensing the water in the atmospheric air by using solar energy, which is a renewable energy source, and thus obtaining potable water are discussed. Efforts to increase the efficiency of obtaining potable water by using various absorbents and by various systemic solar still designs have yielded positive results. As a result of this literature review, the limits of the studies and their regional effectiveness were evaluated together. The effect of temperature, velocity, humidity of the atmospheric air and the amount of solar radiation on the process were evaluated. It has been concluded that certain desiccant materials with good water absorbers such as calcium chloride and silica gel can be used effectively in the processes of obtaining potable water from atmospheric air by developing correct designs. It has been demonstrated that high atmospheric air temperature, which is an important cause of water scarcity, can be converted from disadvantage to advantage by utilizing solar energy.
\end{abstract}

\section{Güneş Damıtıcıları Kullanımı ile Atmosfer Havasından İçilebilir Su Çıkarılması Üzerine Literatür İncelemesi: Son Gelişmeler}

$\ddot{O} \mathbf{z}$

İçme suyu ve kullanma suyu, içme, yemek pişirme ve temizlik başta olmak üzere pek çok yaşamsal ihtiyaçların karşılanmasında vazgeçilmez bir unsurdur. Bilinçsiz tarımsal sulama, kirlilik ve nüfus artışı insanlığın baş etmek zorunda kaldığı su kıtlığına neden olmaktadır. Küresel ısınma ve iklim değişikliği sonucu özellikle içilebilir su miktarı azalmaktadır ve temiz su kaynaklarına erişimi zorlaştırmaktadır. İçme suyu kaynaklarının doluluğu yüksek sıcaklığın yaşandığı mevsimlerde azalmakta ve hatta bir kısmı yok olmaktadır. Bu durum içme suyu elde etmek için alternatif yöntemlerin araştırılmasını zorunlu hale getirmiştir. Bu yöntemlerden biri, yüksek miktarlarda su içeren atmosfer havasından içilebilir su elde edilmesidir. Bu yöntemin yaygın olarak kullanılması sayesinde içme suyu kıtlığı belirli ölçüde giderilebilir. Bu çalışmada, yenilenebilir enerji kaynağı olan güneş enerjisi kullanılarak atmosferik havadaki suyun yoğuşturulması ve böylelikle içilebilir suyun elde edilmesi prosesleri tartışılmıştır. Çeşitli absorbanlar kullanılarak ve çeşitli sistemsel güneş kurutucuları tasarımları sayesinde içilebilir suyu elde etme verimliliğini artırma çabalarının olumlu sonuçlar vermiştir. Yapılan bu literatür incelemesi sonucunda, yapılan çalışmaların sınırları ve bölgesel etkililikleri birlikte değerlendirilmiştir. Atmosfer

*Corresponding Author: $\underline{\text { m.danismaz@ahievran.edu.tr }}$ 
havasının sıcaklı, hız, nem oranı ve de güneş ışınım miktarının prosese etkisi değerlendirilmiştir. Kalsiyum Klorür ve silika jel gibi iyi su absorberleri olan belirli kurutucu malzemelerin doğru tasarımlar geliştirilerek atmosfer havasından içilebilir su elde etme proseslerinde etkin olarak kullanılabileceği sonucuna varılmıştır. Su kıtlığının önemli bir nedeni olan yüksek atmosfer havası sıcaklığın güneş enerjisinden faydalanılarak dezavantajdan avantaja dönüştürülebileceği ortaya konmuştur.

Anahtar Kelimeler: Havadan içilebilir su üretimi, Güneş enerjisi ile su üretimi, Kurutucu, Güneş damıtıcısı.

\section{Introduction}

The three most fundamental requirements for human existence are shelter, clothing, and nourishment. For the first two needs, there are numerous alternatives, but the third is extremely important and has relatively few alternatives. The food must be clean since water is the most important component of the food because it is needed for drinking, cooking, and cleaning. ( $\mathrm{M}$. Kumar, Yadav, \& Mehla, 2019). The amount of earth's water is constant, and it circulates in a closed loop. In addition, just $3 \%$ of all earth water is potable for human utilization in farming, industries, cities, and households. polar ice contains almost three quarter of the earth's drinkable water and human cannot use it, as a result, just a small proportion of the world's water is used by humans(Salehi, Ghannadi-Maragheh, Torab-Mostaedi, Torkaman, \& Asadollahzadeh, 2020). According to studies, 1.1 billion individuals are afflicted by water shortages, as well as 2.7 billion individuals experience droughts at minimum once a year. Due to sanitation concerns with drinkable water, Waterborne illnesses such as cholera, typhoid, and others affect 2.4 billion impoverished people globally. If the current scenario continues, it is anticipated that by 2025 , more than $60 \%$ of the world's population would face major water scarcity difficulties( $\underline{\text { P. M. }}$. Kumar et al., 2021).

The following strategies can be used to tackle the challenge of providing fresh water to desert places( $\underline{\text { A. M. Hamed, Kabeel, }}$ Zeidan, \& Aly, 2010):

1. Water transportation from other regions.

2. Saline water desalination (above and under the surface).

3. Harvesting of water from the ambient air.

The transportation of Water from other sites is frequently costly, especially at first, in those isolated areas. Desalination of salty water (above and undersurface) is very costly, with a high price and a linked to the availability of water(Mohamed, William, \& Fatouh, 2017). The volume of water in the atmosphere is estimated to be $14000 \mathrm{~km}^{3}$, although clean water in rivers and lakes on the planet is around $1200 \mathrm{~km}^{3}$ (A. M. Hamed, Aly, \& Zeidan, 2011). When compared to other ways, this method offers various advantages (decentralized, sustainable, and clean). Furthermore, employing natural resources such as solar energy to alleviate the water problem in remote places is favored. In specifically, the usable area to gather solar radiation and amounts of air are available. Furthermore, this process is an advantageous method for producing fresh water in rural areas and small settlements that are water-scarce(William, Mohamed, \& Fatouh, $\underline{2015}$ ).

To produce drinkable water, water could be harvested from the atmosphere in innovative methods, hence unconventional methods of acquiring water are vital. The methods are:

1. Reducing the air's temperature below the dew point.

2. Fog extraction; and
3. Desiccants can be utilized for capturing moisture from the atmosphere and then regenerate it. (Fathy, Awad, Zeidan, \& Hamed, 2020).

Fog collecting is the oldest method of collecting water droplets that are floating in the atmosphere. Moreover, because this technique requires a continual high atmospheric relative humidity (RH) (100 percent), it is only practicable in a few places( $\mathrm{Li}$ et al., 2018). Many energy conversion processes are necessary during cooling, as well as cooling large amount of air, leading to significant energy waste; this is a very complex and costly technique. ( $\mathrm{Ji}$, Wang, \& Li, 2007).

AWGs (atmospheric water generators) that use solar-thermal methods to harvest and supply water in arid areas are a viable option. This process involves saturating a sorbent with airborne water, then heating it to evaporate and then condense the potable water. (Kim et al., 2018). in order to achieve high performance in these devices, a suitable absorber with a high ability to absorb moisture even in low humidity and with a high ability to release the absorbed moisture even at low temperatures (70 -90 ${ }^{\circ} \mathrm{C}$ ) should be selected. (Li et al., 2018).

To collect water vapor from the atmosphere, desiccant-based AWG might use liquid desiccants (e.g., Calcium chloride), solid desiccants (e.g., $\mathrm{SiO}_{2}$, zeolites, (metal organic frameworks (MOFs)), or (super moisture-adsorbent gels (SMAGs)). The amount of water collected by desiccant-based AWG is proportional to the relative humidity, with the difference in vapor pressure between the absorber surface and atmospheric air functioning as a driving factor for sorption. The desiccant's vapor is forced to desorb onto a cool surface, where it condenses and can be gathered, using heat. In continuous flow modes, desiccants can be operated in a variety of ways, with water collected using a simple heat exchanger. (Mulchandani, Malinda, Edberg, \& Westerhoff, 2020).

\section{Material and Method}

In this section, materials and methods of all literatures are given. Each study was evaluated with its achievements expressing originality in itself.

Harvesting water vapor from ambient air using solar still has been proposed, a liquid desiccant (ethylene glycol) has been used in an (absorption / regeneration) process. The influence of different parameters like relative humidity and temperature on the evaporated moisture from the absorber surface have been studied. A psychometric chart shape used to show the outcomes of the experiment ( $\underline{\text { Hall, 1966) }}$. Sofrata (Gad, Hamed, \& El-Sharkawy, 2001) built an un Orthodox system to harvest water moisture from the ambient using a solid desiccant. Feasibility of using an air conditioning system to extract water from humid air by cooling it to a temperature below the dew point was also examined in the paper.

By soaking the material with a (physico_chemical) liquid and adsorbing humidity from the air, an s-shaped composite material 
was used to produce water from ambient air. The results revealed that the surface's absorptivity decreases as the temperature rises, and that to absorb humidity, the surface must be tilted at 50 degrees. It was possible to produce $1 \mathrm{~L}$ of water $/ \mathrm{m}^{2}$ of composite material (Alayli, Hadji, \& Leblond, 1987).

The mass of water absorbed by the desiccant from the ambient air has been calculated using an analytical approach introduced in this study (Gandhidasan \& Abualhamayel, 1996). As a liquid desiccant, calcium chloride was employed, and a sloped surface exposed to the air has been used as an absorptivity surface. It has been found that the mass of the absorbed water increases by increasing desiccant flow rate, relative humidity of air and wind speed. Abulhamayel and Gandhidasan (Abualhamayel \& Gandhidasan, 1997) Suggested to use an appropriate liquid desiccant for moisture harvesting from the ambient air. The process consists of a nocturnal part where humidity is absorbed and diurnal part where humidity is desorbed at the same unit. The system comprises of a single glass with an air gap of around 45 centimeter covering a flat, painted black, inclined surface. At night, the desiccant flows over the glazing as a thin layer and the desiccant becomes diluted as a result of moisture absorption. At daytime, the diluted desiccant flows over the absorption surface to the downward and it is heated by the solar radiation. the moisture in the desiccant vaporizers and then condenses at the underside of the glazing. about $1.92 \mathrm{~kg} / \mathrm{m}$ of water has been produced.

Aristov et al. (Aristov, Tokarev, Gordeeva, Snytnikov, \& Parmon, 1999) developed (selective water sorbents (SWSs)) which used to extract humidity from the ambiant air. SWSs include host material like silica gel $\left(\mathrm{SiO}_{2}\right)$, alumina (IK_02_200) and porous carbon (subunit), and hygroscopic salts like lithium bromide ( $\mathrm{LiBr}$ ), Calcium Chloride. The outcomes of a lab tests showed the ability of producing ( $(3$ to 5$)$ tones of $\mathrm{H}_{2} \mathrm{O} /$ (10) tones of dry (SWSs)). Gad et al. (Gad et al., 2001) Used a (solar/ desiccant) unit for moisture harvesting from the atmosphere. Absorption of moisture during the night and regeneration of the desiccant and condensing of the Vapor during the day are involved in this process. a thick corrugated cloth stratum impregnated with Calcium Chloride has been used. the flowing of the air over the bed during the night has been done by using a fan. Also, a condensing device has been used (Fig. 1). the process once done without the condenser and one more time with it. The results showed that the efficiency of the system reduces by (5\%) by using the condenser device. A ( $1.5 \mathrm{~L} / \mathrm{m}^{2} /$ day $)$ has been produced.
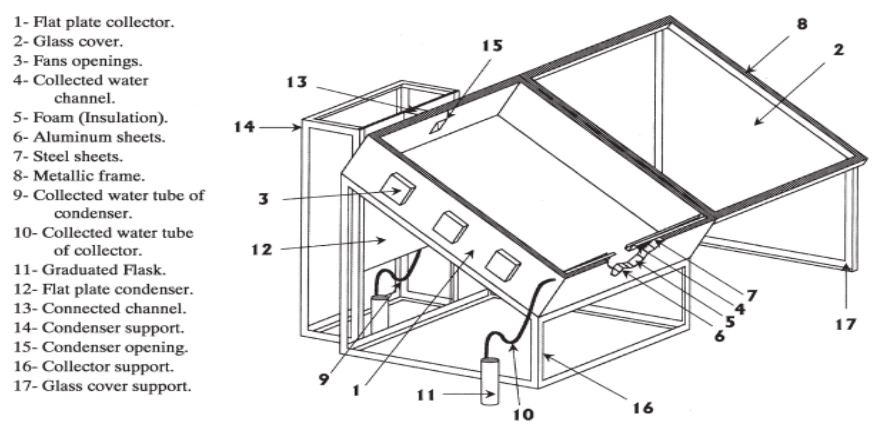

Figure 1. The shape of the experimental device.

In this study (A. Hamed, 2003), Moisture harvesting from the atmospheric air using sand as a bed and calcium chloride as a desiccant has been investigated. Seven stratums were employed, each with a different desiccant/sand ratio ranging from 0.1 to 0.4 . The influence of different variables (absorber concentration and
Grashof number) on the coefficient of mass transfer, in addition to the influence of sand to desiccant mixing proportion on absorption rate were studied. The results showed that the mass transfer increases with increment of the concentration. Also, When the mixing ratio is reduced, mass transfer can be seen to rapidly diminish. Kabeel (Kabeel, 2004) used a system comprises of a (Solar/collector) unit containing a sandy bed impregnated with a liquid desiccant (Calcium Chloride) to extract moisture from the atmosphere. The system has been tested with three various inclination angles $(15,20$, and 25 degree $)$. A mathematical paradigm has been prepared for testing the influence of different parameters. The results revealed that $\left(1.2 \mathrm{~L}\right.$ of water $/ \mathrm{m}^{2} /$ day $)$ have been collected and the best results can be obtained by using a tilt angle of $\left(25^{\circ}\right)$.

The goal of this research (Scrivani, El Asmar, \& Bardi, 2007) is to develop uses for the Solar trough concentration other than heat and refrigeration, such as extracting fresh water from the atmosphere. This was accomplished through utilization of a solar concentrator and a double-effect ammonia chiller. It has the advantage of using the solar energy for both heating up the air and condensing the air moisture by using a chiller. Only two instruments are needed, both of which are solar-powered and do not require any further energy sources, save for the troughs to be directed and the diathermic fluid to be pumped through the Collector. Potable water and the best results can be achieved by using a tilt angle of $\left(25^{\circ}\right)$.

Two identical pyramids shaped multi shelf Solar System have been used to harvest moisture from the ambient air (Fig. 2). the two systems are same in the dimensions but different in the bed type. $\mathrm{CaCl}_{2}$ with $30 \%$ concentration has been used as a desiccant material (Kabeel, 2007). Saw wood used as a bed in the first pyramid, whereas cloth has been used in the second one. The investigations were carried out in various environmental situations in order to investigate how the absorption / desorption process can be influenced by the shape (pyramid) of the apparatus. The outcomes revealed that the absorptivity of cloth bed is more than the absorptivity of the saw wood. a $\left(2.1 \mathrm{Liter} / \mathrm{m}^{2}\right.$. day) of potable $\mathrm{H}_{2} \mathrm{O}$ has been collected.

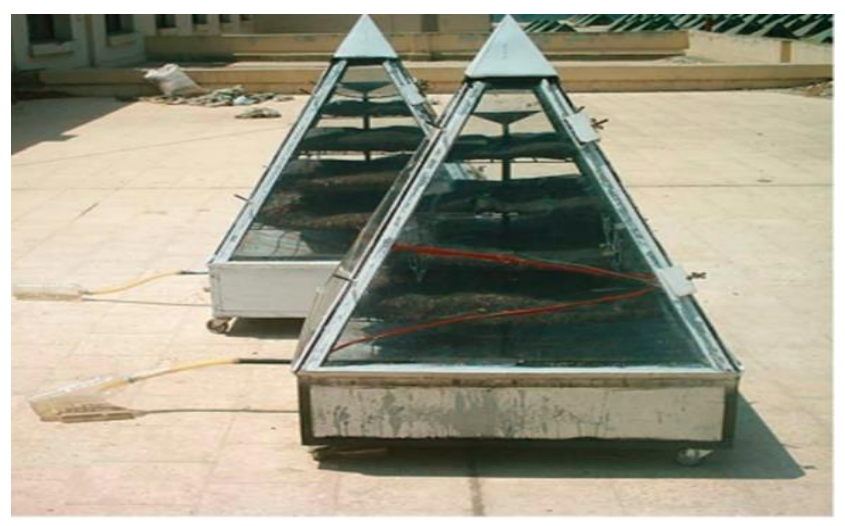

Figure 2. Image of the device.

Kabeel (Kabeel, 2007) Introduced a new Composite adsorbent with high efficiency for harvesting water from the ambient air using solar energy. The composite material (mcm-41) consists of an enormous pore Crystalline material, used like host material as well as $\mathrm{CaCl}_{2}$ used like desiccant. According to the outcomes, the composite material has an adsorption capacity of $(1.75 \mathrm{~kg} / \mathrm{kg}$ of desiccant) and the adsorption rate was found to be interesting, and the regeneration process does not need high temperatures to occur. $\left(1.2 \mathrm{~kg} / \mathrm{m}^{2}\right)$ of water has been produced. Bardy described how 
solar concentration can be used to harvest potable water from the atmosphere. The (AQUASOLIS) project's findings were used to evaluate the utility of solar basin concentration systems for purposes besides heating /cooling, particularly water generation for various applications (Bardi, 2008).

A suitable absorber/disrober was built to gather the moisture present in the humid atmosphere (Fig. 3). $\mathrm{CaCl}_{2}$ was used as desiccant material. Four different desiccant flow rates and concentrations of desiccant were used in the experiments $(32.5 \%$ - $33.5 \%$ ) (Gandhidasan \& Abualhamayel, 2010). The results revealed that increasing ambient air temperature, wind speed, solution concentration, and reducing desiccant flow rate enhances absorption efficiency, whereas increasing solar radiation, ambient air temperature, and decreasing desiccant flow rate increases desorption rate. The moisture absorption rate found to be $(2.11$ Liter $/ \mathrm{m}^{2} /$ day) based on the absorbent flow rate, while the water evaporation rate found to be $\left(1.15 \mathrm{Liter} / \mathrm{m}^{2} /\right.$ day $)$.

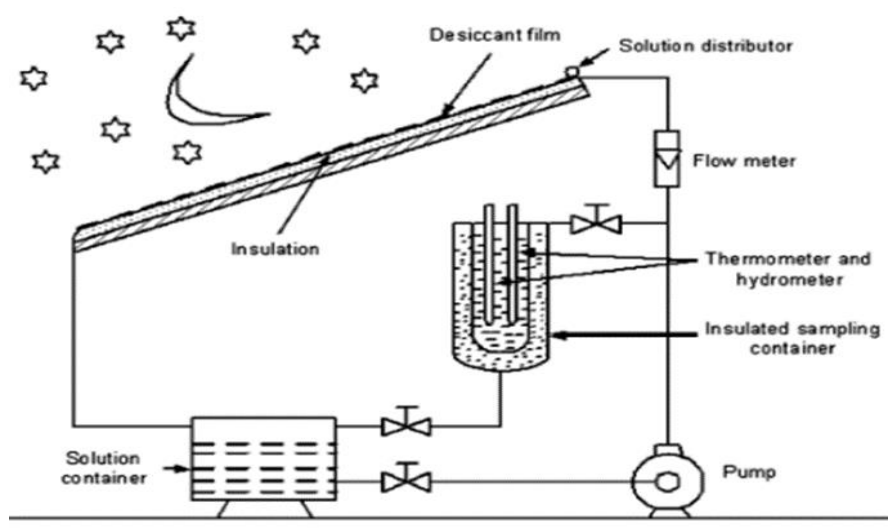

Figure 3. Schematic of the experimental apparatus.

A sandy bed saturated with $\mathrm{CaCl}_{2}$ used to capture moisture from atmospheric air was investigated (A. M. Hamed et al., 2011). the goal of this research is to see how the productivity of the system can be affected by various parameters during the regeneration. For this objective, an experimental device has been devised and built. It consists of a (solar/desiccant) collector with a surface area of $(0.5 \mathrm{~m})$. During the night, the sandy bed is exposed to the atmosphere to absorb moisture, and the desiccant is regenerated, and water vapor is condensed in the daytime. $\left(1 \mathrm{~L} / \mathrm{m}^{2}\right)$ of pure water has been produced.

An alternate approach for producing drinkable water from the atmosphere was investigated in this research. By utilizing (solarbased thermoelectric generators), the investigated technology is suited for Arabic Gulf countries or similar regions. (Star-CCM+) was used to run a simulation. Various parameters have been studied in three various climate regions (Red Sea, Arabic gulf, South Spain). The findings revealed that the volume of produced water was $\left(3.9 \mathrm{~L} / \mathrm{h} / \mathrm{m}_{2}\right)$ when the pumping energy needed for the air fan was not exceeded (9.1w) (Kabeel, Abdulaziz, \& El-Said, $\underline{2016)}$.

Experiments have been carried out on a novel composite material used in collecting as well as producing $\mathrm{H}_{2} \mathrm{O}$ from the atmosphere. Three solar glass box shaped system with $0.36 \mathrm{~m}^{2}$ collecting area were used. Six different concentrations of $\left(\mathrm{CaCl}_{2}\right)$ patterns were prepared and employed in the tests. The results revealed that the amount of the absorbed moisture in the nighttime, the temperature of (internal space of the apparatus and the composite material), the quantity of the generated water in the daytime, all boosts with rise of $\mathrm{CaCl}_{2}$ concentration. The e-ISSN: 2148-2683 maximum productivity using the composite material found to be (180 mLof water $/ \mathrm{Kg}$ of desiccant/day) at $60 \%$ concentration (Manoj \& Avadhesh, 2015).

Experiments were conducted in this work to determine the ability of a newly created composite desiccant material $\left(\mathrm{CaCl}_{2} /\right.$ flower foam) to remove water from ambient air. Floral foam has been used like a bed and Calcium Chloride like a desiccant. Three (solar glass box shaped system (SGDBS)) have been used (Fig. 4). Six patterns of $\left(\mathrm{CaCl}_{2}\right)$ with different concentrations have been prepared and used. The greatest adsorption rate $(0.043992 \mathrm{Kg} / \mathrm{h})$ and water production $\left(0.35 \mathrm{~mL} / \mathrm{Cm}^{3} /\right.$ day $)$ have been observed at (37\%) concentration of Calcium Chloride. As the concentration of $\left(\mathrm{CaCl}_{2}\right)$ rises, The collected water amount also increases $(\underline{\mathrm{M}}$. $\underline{\text { Kumar \& Yadav, 2016). }}$

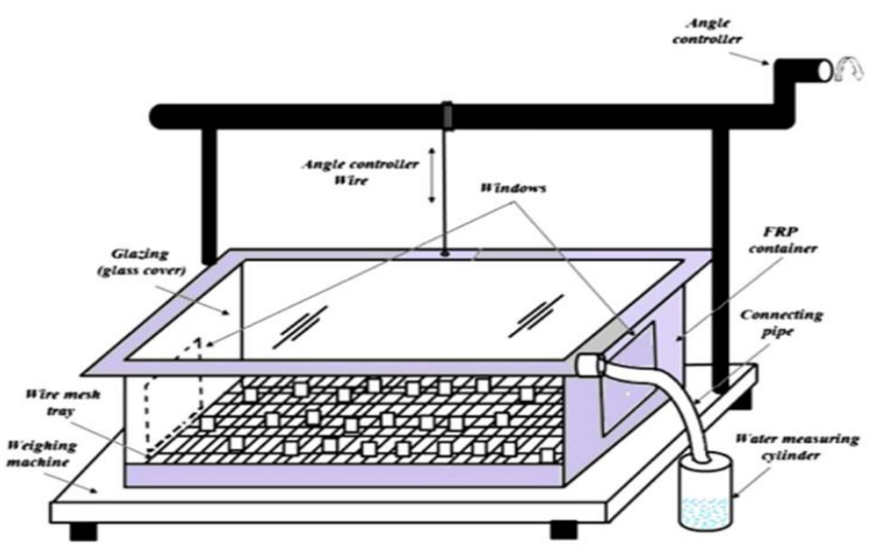

Figure 4. Schematic of the apparatus used in the experiment.

The studies were carried out to identify the design parameters for harvesting drinkable water from the atmospheric air: air gap elevation, tilt angle, appropriate thickness of glass, and appropriate number of glass. Silica gel $\left(\mathrm{SiO}_{2}\right)$ used as a solid desiccant. Three (SGBDs) systems have been used. The results revealed that appropriate glass thickness $(3 \mathrm{~mm})$, the air gap elevation $(0.22 \mathrm{~m})$, tilt angle $\left(30^{\circ}\right)$, and single glazing are the design criteria for maximum production. During the experiment, the highest amount of freshwater generated was $(200 \mathrm{~mL} / \mathrm{Kg}$ of desiccant/day) (M. Kumar \& Yadav, 2015).

William et al., designed and built a trapezoidal prism absorber with 4 fiberglass surfaces (Fig. 5). To optimize bed surface area inside the Collector, the Collector constructed with a multishelves bed. Beds used in this test were Sand and cloth layers and the desiccant used was $\left(\mathrm{CaCl}_{2}\right)$ with $(30 \%)$ concentration. Outcomes revealed that with $30 \% \mathrm{CaCl}_{2}$ concentration, the total desorbed vapor amount for cloth bed was (2.32 slit/ days. $\left.\mathrm{m}^{2}\right)$, while for sandy bed was (1.23 slit/day.m2). For cloth and Sand, the system efficiency is $(29.3 \%)$ and $(17.76 \%)$, respectively (William et al., 2015).

Kumar et al., Studied and tested a new composite absorbing material (Calcium Chloride _vermiculite with saw wood) which serves as a water harvester from the ambient air (Vermiculite with saw wood) used like a bed and Calcium Chloride like a desiccant. 


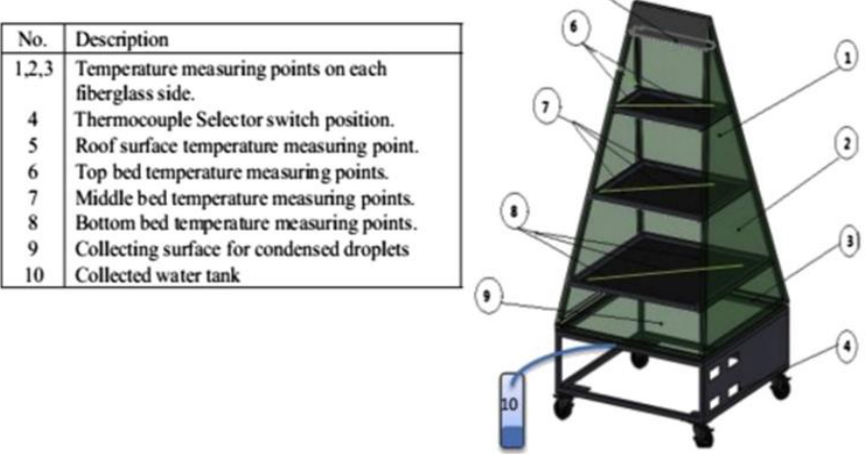

Figure 5. Schematic diagram of the device used in the test.

Six patterns of $\left(\mathrm{CaCl}_{2}\right)$ with various concentrations have been prepared and used in a (solar glass box type system (SGDBS)) with tilted angle $\left(30^{\circ}\right)$. Using $(2.5 \mathrm{Kg})$ of composite desiccant, the optimum amount of generated water is $\left(500 \mathrm{~mL} / \mathrm{m}^{2} /\right.$ day $)$ and the desiccant concentration has the greatest impact on water output (M. Kumar \& Yadav, 2017).
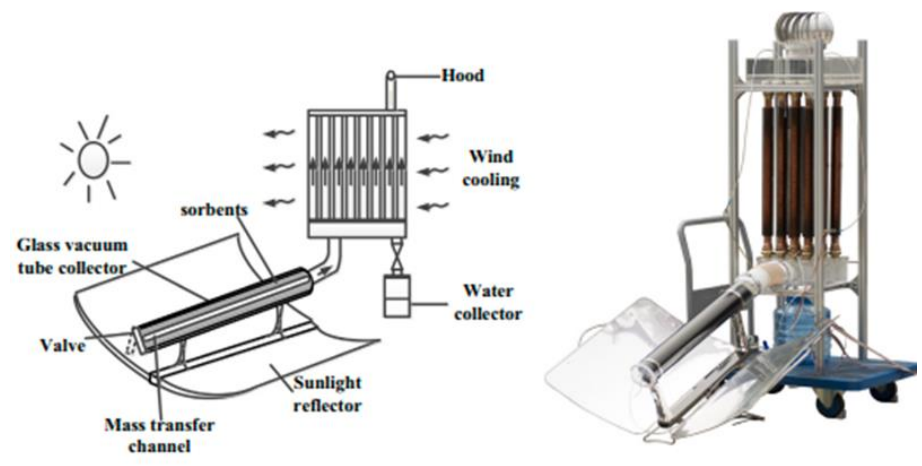

Figure 6. (a) Schematic diagram, (b) The apparatus shape.

A very efficient (semi-open) system for producing drinkable water was built. The material employed was an active carbon felt (ACF) composite material containing Nano silica particles packed in pure active carbon felt fiber that had been gap soaked in lithium chloride. The structure of the composite material is corrugated, allowing it to be simply molded into mass transmission channels. CFX is used to examine the sorbent unit. It has been found that as (relative humidity, the amount of absorbed water, and as desorption temperature) rise, the amount of released water rises. $(40.8 \mathrm{~kg})$ of composite material was used to collect $(14.7 \mathrm{~kg})$ of water (Wang, Wang, Wang, \& Liu, 2017).

Two solar-powered devices, an (open kind) apparatus and an (enhanced semi open kind) device (Fig. 6), are conceived and built to collect potable water from the ambient air using the sorption method. At 70-80 degrees Celsius, the solar collector can drive both. Using a concept device with a roll-up form with 2.25 kilogram of the absorber (ACF-CaCl 2 ) led to collect $0.32 \mathrm{~kg}$ of fresh water. The improved semi-open type system catches 9 kilograms of potable water using a $4 \mathrm{~m}^{2}$ solar collector surface, corrugated plus flat adsorbents are built for loading 40.8 kilograms of ACF- $\mathrm{LiCl}$ adsorbent with a $(0.4 \times 0.4 \times 0.6 \mathrm{~m})$ bed (Wang, Liu, Wang, \& Wang, 2017).

The goal of this theoretical and experimental investigation is to determine the factors that influence the performance of a finned portable light weight device for harvesting potable water from ambient air using $\left(\mathrm{CaCl}_{2}\right)$ as a desiccant. During the night, a finned double-faced conical absorber is designed and built to absorb moisture from ambient air. A (transparent double-faced conical cover) is used as a condensation Surface during daytime. The system's productivity ranges from 0.3295 to 0.6310 $\mathrm{Kg} / \mathrm{m}^{2} /$ day, and the produced water costs $(0.062$ Dollar $/ \mathrm{Kg})$ (Talaat, Awad, Zeidan, \& Hamed, 2018).

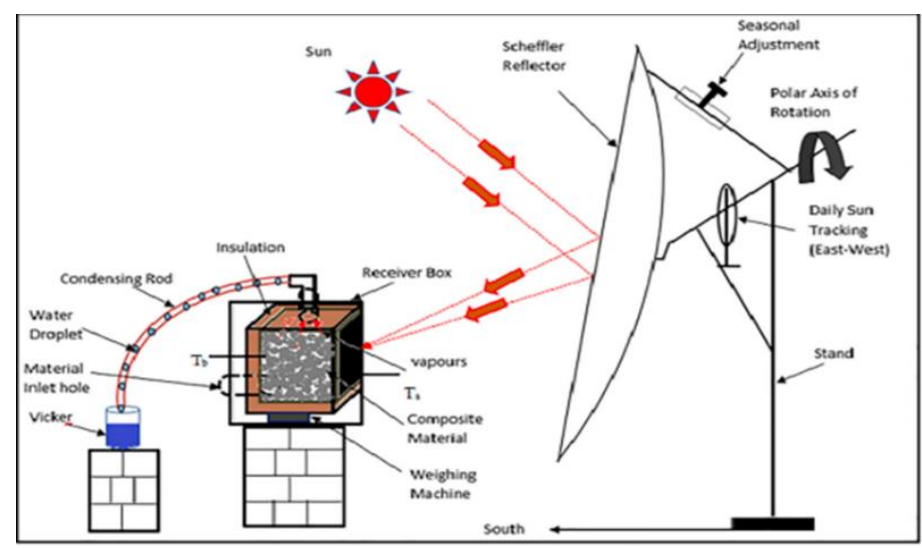

Figure 7. Schematic diagram of the apparatus.

In another study, experimental checking has been done to extract moisture from the ambient air using three various composite material consist of (Lithium Chloride/sand (CM_1), Calcium Chloride /sand (CM_2), Lithium Bromide/sand (CM_3)) with $37 \%$ concentration of the desiccant with sand used like a bed. (absorption / desorption) processes have been used to harvest moisture from the atmospheric air. During the day, a newly built $\left(1.54 \mathrm{~m}^{2}\right)$ Scheffler reflector is used for the regeneration process (Fig.7). The optimum amount of the collected water from (CM_1, CM_2, CM_3) are (90 ml/day, $115 \mathrm{ml} /$ day, $73 \mathrm{ml} /$ day $)$, respectively. The yearly cost for the generated water is $(0.71$ Dollar, 0.53 Dollar and 0.86 Dollar) respectively ( $\underline{\text { Srivastava \& }}$ Yadav, 2018).

The goal of this study is to see how different operation conditions can affect the system performance. Calcium chloride with various initial concentrations has been used as a desiccant material. Water productivity using sandy bed and black cloth has been studied, a mathematical model has been prepared to investigate the system operation during the desorption period. The total amount of water produced was around $\left(3.02 \mathrm{~L} / \mathrm{m}^{2}\right.$.day) (Mohamed et al., 2017). Kumar et al. compared between the performance of three types of desiccant composite materials (vermiculite with saw wood, jute, and burnt clay). $\mathrm{CaCl}_{2}$ with $37 \%$ concentration has been used as a desiccant in a box shaped apparatus with a collecting area of $0.36 \mathrm{~m}^{2}$. They determined that the highest productivity of the system obtained using vermiculitesaw wood/Calcium Chloride on the test day was 130 $\mathrm{mL} /($ Kg.day) (M. Kumar et al., 2019).

Kim et al. presented a water collecting device that used a 'metal-organic framework (MOF)-801' as an absorber in an extremely arid environment (10\% - $40 \% \mathrm{RH})$. They used black paint on the backside of the MOF to act as a solar absorber. They predicted that $0.25 \mathrm{~L}$ of water / $\mathrm{Kg}$ of MOF can be produced in a single day. They used MOF-801 to examine the produced water and discovered that MOF structure has stability against water, with no metal ions or organic linkers polluting the water (Kim et al., 2018).

A supple water absorber consists of salt $\left(\mathrm{CaCl}_{2}\right)$ and hydrogel (PAM-CNT) had been prepared. At field conditions, a simple-toassemble prototype apparatus containing $35 \mathrm{~g}$ of dry hydrogel (PAM-CNT-CaCl 2 ) was used. Under sunlight, the amount of 
generated water was found to be $20 \mathrm{~g}$ in 2.5 hours. The materials used in building such an equipment to supply minimum daily water intake for a person $(3 \mathrm{~kg}$ ) is estimated to cost only 3.2 dollars ( $\underline{\text { Li et al., 2018). }}$.

A (super moisture absorbent gel) used to accomplish high efficiency water production by (atmospheric water harvesting $(\mathrm{AWH})$ ) in a wide range of $\mathrm{RH}$. This design is a unique way to enhance the AWH, since it has been discovered to be an effective means of regulating water molecule movement (Zhao et al., $\underline{2019)}$.

The extraction of water vapor from the ambient air with adsorption process in dry locations utilizing sunlight is the subject of this study. The (Metal-organic frameworks (MOFs) has been used as the desiccant material. The quantitative needs for the optimal adsorbent are expressed by the values of $\Delta \mathrm{F}_{\mathrm{ad}}$ and $\Delta \mathrm{F}_{\mathrm{re}}$ for three dry climate areas (the desert of Sahara, KSA, and Central Australia). The most viable MOFs for Australia appear to be MIL$101(\mathrm{Cr}), \mathrm{Co}_{2} \mathrm{Cl}_{2}$ (BTDD), and MIL-101(Cr)-SO $\mathrm{S}_{3} \mathrm{H}$. For KSA and Sahara, MIL-160 and CAU-10(pydc) are appropriate. At the regeneration temperature of $75-100{ }^{\circ} \mathrm{C}$, they swap 0.34 to 1.6 (gram of water)/ (gram of desiccant) as well as enabled the portions ${ }^{\delta} \mathrm{ex}=0.78-0.93$ moisture removal and ${ }^{\delta} \operatorname{col} 140.75$ to 0.90 freshwater collection to be obtained. (Gordeeva, Solovyeva, Sapienza, \& Aristov, 2020).

Freshwater collection from the atmosphere through the utilization of a (tubular solar still) was performed experimentally in Hail City, Ksa, with exceptionally low humid air conditions $(12 \%)$. The desiccant $\left(\mathrm{CaCl}_{2}\right)$ placed in a rectangular basin with a (black cotton cloth) as a bed. A tiny air blower has been added to the apparatus for circulating the atmospheric air during the nocturnal process. Under five distinct air velocity circumstances (natural, $0.5 \mathrm{~m} / \mathrm{s}, 1 \mathrm{~m} / \mathrm{s}, 3 \mathrm{~m} / \mathrm{s}$, and $4 \mathrm{~m} / \mathrm{s}$ ), studies on the absorption process have done. During the day, the air fan turned off and closing the sides of the tube has done, leading the water in the desiccant solution to evaporate, and then condense on the inner surface of the tube in the regeneration operation, and the water droplets removed outside the apparatus. The highest water production was $467 \mathrm{~mL} / \mathrm{m}^{2}$.day with a 25 percent thermal efficiency for a $4 \mathrm{~m} / \mathrm{s}$ air speed, and the less amount of produced water found to be $230 \mathrm{~mL} / \mathrm{m}^{2}$.day with a 12.2 percent thermal efficiency for natural air circulation. The cost of producing freshwater was $0.4 \$$ per liter for natural air circulation and $0.2 \$$ per liter for $4 \mathrm{~m} / \mathrm{s}$ air velocity (Elashmawy, 2020).

Fathy et al. carried out a theoretical and experimental study for harvesting potable water from atmospheric air using foldable apparatus with accordion shape (Fig. 8). $\mathrm{CaCl}_{2}$ has been used as a desiccant material and a layer of black cotton cloth as a bed. Mathematical model has been prepared to simulate the process and the cost analysis has been used to assess the apparatus' economic cost of water production. The findings revealed that the volume of produced water can approach $750 \mathrm{~g} /$ day, with a cost of roughly $0.086 \$ / \mathrm{Kg}$ (Fathy et al., 2020).

The present study introduces a new technique to collect water vapor from the ambient air in regions with very low humidity. The experiment is conducted in Hail, a Saudi Arabian city. The suggested system's concept was to use a solar concentrator to increase the bed temperature in the absorption process. TSS's capacity to evaporate moisture from a powerful desiccant of $\mathrm{CaCl}_{2}$ at extremely low humidity might be improved by this approach.

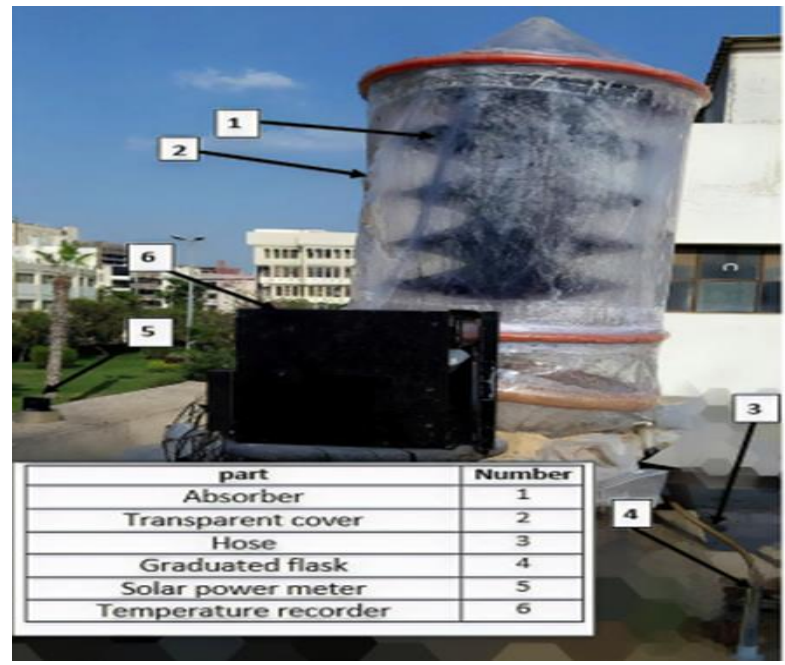

Figure 8. Photograph of the device.

The suggested method produced 0.51 liters per kilogram of $\mathrm{CaCl}_{2}$. Thermal efficiency found to be 24.61 percent for the system, while the cost of producing water was $\$ 0.15$. TSS productivity and efficiency increased by 292.4 and 82.3 percent, respectively, whereas water production expenses were reduced by $25 \%$. The proposed system was small, light, and transportable, allowing it to be used in deserts, remote locations, and isolated locations with no need for water (Elashmawy \& Alshammari, 2020). The thermal performance of a 'double-slope half cylindrical basin solar still (DS-SHCBSS)' (Fig. 9) to harvest water from the ambient air using $\mathrm{SiO}_{2}$ was tested in an experiment. Two improvements were considered: adding longitudinal fins within the trough as well as using gravels in the trough. A parabolic solar collector was used to increase the heat within the solar still in desorption process. the productivity under various input factors has been predicted using a mathematical model. The results showed that using the longitudinal fins and longitudinal fins with gravels boosts the productivity by nearly $72 \%$ and $166 \%$ respectively, and the system efficiency by nearly $15 \%$ and $35 \%$ respectively. The highest water productivity found to be $400 \mathrm{~mL} / \mathrm{m}^{2}$ (Essa et al., 2020).

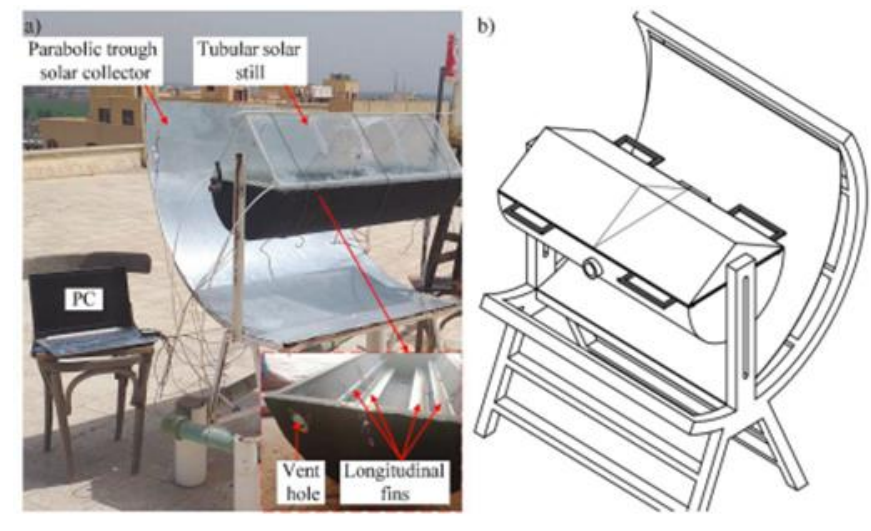

Figure 9. Experimental device (a) a photograph, (b)schematic diagram.

This study aims to supply heat source in order to enhance desiccant surface temperature, developing the water vapor regeneration, and allowing extra (atmospheric water capture (AWC)) cycles/ day by attaching nanomaterials (gold cubes and rods (AuNC, AuNR), carbon black (CB)). The adsorption processes of the desiccants were tested under various relative humidity (40, 60 and 80\%) and (1-sun simulated solar irradiation) 
is used for the desorption process. The results revealed that silica gel coated with carbon black could cycle more than 10 times adsorption-desorption processes and produces $(0.47 \mathrm{~g}$ of potable water / g of desiccant) in 12 hours (Mulchandani et al., 2020).

Kumar et al. investigated the water productivity from atmospheric air using solar restoration system with orange $\mathrm{SiO}_{2}$ as a desiccant material. They coated the backside of the absorber surface with a black paint in order to enhance the absorptivity of the system (fig.10). The results revealed that $0.98 \mathrm{~L} /$ day can be produced (P. M. Kumar et al., 2021).

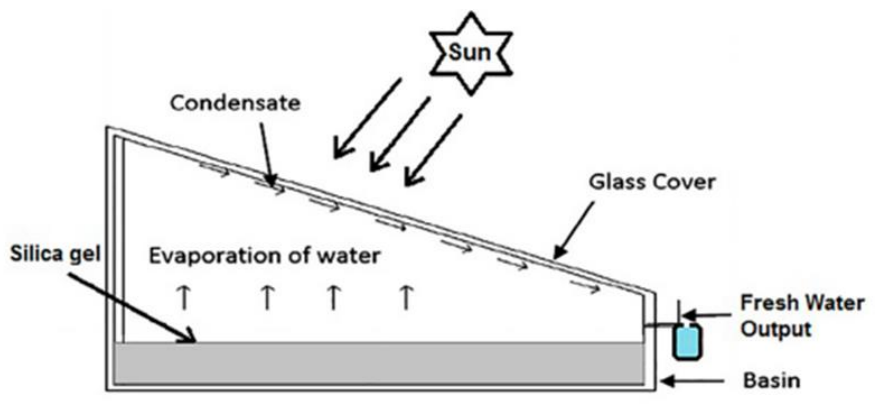

Figure 10. A schematic diagram of the system.

\section{Results and Discussion}

From all papers discussed above, we can reveal that: Devices with various shapes have been constructed to capture water from atmospheric air, e.g.; double-faced conical shaped (Talaat et al., $\underline{2018}$ ), Accordion shaped (Fathy et al., 2020), trapezoidal shaped (William et al., 2015), pyramid shaped (Kabeel, 2007), and box shaped (Gad et al., 2001). The pyramid shaped and trapezoidal shaped devices showed higher productivity than other devices, because these methods boost bed surface area inside the collector, they improve absorption and evaporation surfaces while also allowing condensation to occur on all four sides.

Water harvesting from humid air is done with several types of desiccants, either solid (e.g., $\left.\mathrm{SiO}_{2}\right)$ or liquid $\left(\mathrm{CaCl}_{2}\right)$, and experiments have been carried out to see if increasing the desiccant amount leads to an increase in the quantity of produced fresh water or not. It has been discovered that increasing $\mathrm{SiO}_{2}$ amounts improves not just the moisture absorption from the atmosphere during the night, but also the absorption of solar energy and the evaporation operation throughout the day (Essa et al., 2020). At the same regeneration situation, the substance temperature rises as the percentage of Calcium chloride increases. This is because as the concentration of Calcium chloride rises, the mass of Calcium chloride in the host material rises, increasing the adsorption capability for the moisture content in the sample ( $\underline{M}$. Kumar \& Yadav, 2017).

Liquid desiccants require bed (host material) in order to hold the desiccant within the apparatus during the process. Different types of beds have been used by the researchers to produce composite materials (bed / desiccant), e.g. sand, black cloth, saw wood (Manoj \& Avadhesh, 2015), vermiculite- saw wood (M. Kumar \& Yadav, 2017), floral foam (M. Kumar \& Yadav, 2016), ACF (Wang, Liu, et al., 2017), Alg (Kallenberger \& Fröba, 2018), and PAM-CNT (Li et al., 2018). Comparisons have done between sandy bed and cloth layer (Mohamed et al., 2017), and between saw wood and cloth layer (Kabeel, 2007). The results revealed that cloth layer has higher water productivity than both sandy bed and saw wood, and this is due to its high liquid capacity and porosity. Studies have been done to investigate the influence of increasing the number of bed layers, experiments carried out by studying cloth layers at 4 and 6 , and sandy bed at $8 \mathrm{~kg} / \mathrm{m}^{2}$ and 12 $\mathrm{kg} / \mathrm{m}^{2}$. The findings revealed that increasing the number of bed layers had a marginally beneficial impact on system performance (William et al., 2015).

Parameters that affect the performance of the system can be classified into:

1- Weather conditions: Weather conditions during the night are among the most critical aspects in the absorption process (relative humidity, atmospheric temperature, and wind velocity). The mass transfer coefficient is proportional to the wind speed, which works as a forced convection cooling source (Kim et al., 2018). As a result, the absorbed water rate rises as the mass transfer coefficient rises (Gordeeva et al., 2020). The ambient vapor pressure is directly proportional to the relative humidity (William et al., 2015). So, as relative humidity and wind speed increases, so does the amount of absorbed water in the bed, as well as evaporation and system efficiency. Owing to the fact that water regeneration happens in solar time, the regeneration process is affected by changes in weather conditions around daytime. As the temperature of the bed rises, the vapor pressure of the solution on the bed surface rises, creating a vapor pressure difference between the bed surface and the glass cover, resulting in water evaporation from the bed to the glass cover and condensation at the glass cover. As a result, an increase in solar radiation causes an increase in evaporation and system productivity. (Mohamed et al., 2017)

2- Design parameters of the apparatus: studies have been carried out to evaluate the influence of various design parameters, e.g., air gap elevation $(0.10,0.16,0.22 \mathrm{~m})$, tilt angle of the device $\left(10,20,30^{\circ}\right)$, thickness of the glass $(3,5,8 \mathrm{~mm})$, and number of glazing (single, double, triple). According to the results, air gap elevation of $0.22 \mathrm{~m}$, tilt angle of 30 , efficient thickness of glass of $3 \mathrm{~mm}$, and number of glazing as single are the design parameters for maximal water generation from the atmosphere (M. Kumar \& Yadav, 2015).

Researchers used a variety of modifications to improve water production from the atmosphere, such as using a parabolic concentrator to concentrate solar radiation in a fixed point (Elashmawy \& Alshammari, 2020), (Srivastava \& Yadav, 2018), increasing the number of shelves (Kabeel, 2007), (William et al., $\underline{2015}$ ) or installing fins (Essa et al., 2020) inside the apparatus to increase the surface area of the apparatus as well as the amount of desiccant used within the device, and Gravels are used to raise the desiccant's operating temperature because they have a high solar absorptivity and specific heat, making them an excellent absorber of solar energy and thermal energy storage (William et al., 2015).

\section{Conclusions and Recommendations}

The amount of drinkable water is dwindling, making clean water supplies difficult to come by. As a result of this circumstance, it has become essential to look for alternate sources of drinking water. One of these ways is to extract drinkable water from high-water-content atmospheric air. The limitations of the research, as well as their geographical efficacy, were assessed as a consequence of this literature study. Temperature, velocity, humidity of the atmospheric air, and the quantity of solar radiation all had an impact on the process. By constructing appropriate designs, it has been found that some desiccant materials with good water absorbers, such as calcium chloride and silica gel, may be 
employed successfully in the procedures of getting drinkable water from ambient air. It has been proved that by employing solar energy, high ambient air temperature, which is a major source of water shortage, may be turned from a disadvantage to an advantage.

\section{References}

Abualhamayel, H., \& Gandhidasan, P. (1997). A method of obtaining fresh water from the humid atmosphere. Desalination, 113(1), 51-63.

Alayli, Y., Hadji, N., \& Leblond, J. (1987). A new process for the extraction of water from air. Desalination, 67, 227-229.

Aristov, Y. I., Tokarev, M., Gordeeva, L., Snytnikov, V., \& Parmon, V. (1999). New composite sorbents for solar-driven technology of freshwater production from the atmosphere. Solar Energy, 66(2), 165-168.

Bardi, U. (2008). Fresh water production by means of solar concentration: the AQUASOLIS project. Desalination, 220(1-3), 588-591.

Elashmawy, M. (2020). Experimental study on water extraction from atmospheric air using tubular solar still. Journal of Cleaner Production, 249, 119322.

Elashmawy, M., \& Alshammari, F. (2020). Atmospheric water harvesting from low humid regions using tubular solar still powered by a parabolic concentrator system. Journal of Cleaner Production, 256, 120329.

Essa, F., Elsheikh, A. H., Sathyamurthy, R., Manokar, A. M., Kandeal, A., Shanmugan, S., . . . Younes, M. (2020). Extracting water content from the ambient air in a doubleslope half-cylindrical basin solar still using silica gel under Egyptian conditions. Sustainable Energy Technologies and Assessments, 39, 100712.

Fathy, M. H., Awad, M. M., Zeidan, E.-S. B., \& Hamed, A. M. (2020). Solar powered foldable apparatus for extracting water from atmospheric air. Renewable energy, 162, 1462-1489.

Gad, H., Hamed, A., \& El-Sharkawy, I. (2001). Application of a solar desiccant/collector system for water recovery from atmospheric air. Renewable energy, 22(4), 541-556.

Gandhidasan, P., \& Abualhamayel, H. (1996). Water recovery from the atmosphere. Renewable energy, 9(1-4), 745-748.

Gandhidasan, P., \& Abualhamayel, H. (2010). Investigation of humidity harvest as an alternative water source in the Kingdom of Saudi Arabia. Water and Environment Journal, 24(4), 282-292.

Gordeeva, L. G., Solovyeva, M. V., Sapienza, A., \& Aristov, Y. I. (2020). Potable water extraction from the atmosphere: Potential of MOFs. Renewable energy, 148, 72-80.

Hall, R. C. (1966). Theoretical calculations on the production of water from the atmosphere by absorption with subsequent recovery in a solar still. Solar Energy, 10(1), 41-45.

Hamed, A. (2003). Experimental investigation on the natural absorption on the surface of sandy layer impregnated with liquid desiccant. Renewable energy, 28(10), 1587-1596.

Hamed, A. M., Aly, A. A., \& Zeidan, E.-S. B. (2011). Application of solar energy for recovery of water from atmospheric air in climatic zones of Saudi Arabia. Natural Resources, 2(01), 8.

Hamed, A. M., Kabeel, A., Zeidan, E.-S. B., \& Aly, A. A. (2010). A technical review on the extraction of water from atmospheric air in arid zones. Int. J. Heat Mass Trans, 4, 213 228.
Ji, J., Wang, R., \& Li, L. (2007). New composite adsorbent for solar-driven freshwater production from the atmosphere. Desalination, 212(1-3), 176-182.

Kabeel, A. (2004). Application of sandy bed solar collector system for extraction of water from air. Paper presented at the 8th International Water Technology Conference.

Kabeel, A. (2007). Water production from air using multi-shelves solar glass pyramid system. Renewable energy, 32(1), 157172.

Kabeel, A., Abdulaziz, M., \& El-Said, E. M. (2016). Solar-based atmospheric water generator utilisation of a freshwater recovery: A numerical study. International Journal of Ambient Energy, 37(1), 68-75.

Kim, H., Rao, S. R., Kapustin, E. A., Zhao, L., Yang, S., Yaghi, O. M., \& Wang, E. N. (2018). Adsorption-based atmospheric water harvesting device for arid climates. Nature communications, 9(1), 1-8.

Kumar, M., \& Yadav, A. (2015). Experimental investigation of design parameters of solar glass desiccant box type system for water production from atmospheric air. Journal of Renewable and Sustainable Energy, 7(3), 033122.

Kumar, M., \& Yadav, A. (2016). Solar-driven technology for freshwater production from atmospheric air by using the composite desiccant material " $\mathrm{CaCl} 2$ floral foam". Environment, Development and Sustainability, 18(4), 11511165.

Kumar, M., \& Yadav, A. (2017). Composite desiccant material "CaCl 2/Vermiculite/Saw wood": a new material for freshwater production from atmospheric air. Applied Water Science, 7(5), 2103-2111.

Kumar, M., Yadav, A., \& Mehla, N. (2019). Water generation from atmospheric air by using different composite desiccant materials. International Journal of Ambient Energy, 40(4), 343-349.

Kumar, P. M., Arunthathi, S., Prasanth, S. J., Aswin, T., Antony, A. A., Daniel, D., . . Babu, P. N. (2021). Investigation on a desiccant based solar water recuperator for generating water from atmospheric air. Materials Today: Proceedings, 45, 7881-7884.

Li, R., Shi, Y., Alsaedi, M., Wu, M., Shi, L., \& Wang, P. (2018). Hybrid hydrogel with high water vapor harvesting capacity for deployable solar-driven atmospheric water generator. Environmental science \& technology, 52(19), 11367-11377.

Manoj, K., \& Avadhesh, Y. (2015). Experimental investigation of solar powered water production from atmospheric air by using composite desiccant material" $\mathrm{CaCl} 2 / \mathrm{saw}$ wood". Desalination, 367, 216-222.

Mohamed, M., William, G., \& Fatouh, M. (2017). Solar energy utilization in water production from humid air. Solar Energy, 148, 98-109.

Mulchandani, A., Malinda, S., Edberg, J., \& Westerhoff, P. (2020). Sunlight-driven atmospheric water capture capacity is enhanced by nano-enabled photothermal desiccants. Environmental Science: Nano, 7(9), 2584-2594.

Salehi, A. A., Ghannadi-Maragheh, M., Torab-Mostaedi, M., Torkaman, R., \& Asadollahzadeh, M. (2020). A review on the water-energy nexus for drinking water production from humid air. Renewable and Sustainable Energy Reviews, 120, 109627.

Scrivani, A., El Asmar, T., \& Bardi, U. (2007). Solar trough concentration for freshwater production and wastewater treatment. Desalination, 206(1-3), 485-493. 
Srivastava, S., \& Yadav, A. (2018). Water generation from atmospheric air by using composite desiccant material through fixed focus concentrating solar thermal power. Solar Energy, 169, 302-315.

Talaat, M., Awad, M., Zeidan, E., \& Hamed, A. (2018). Solarpowered portable apparatus for extracting water from air using desiccant solution. Renewable energy, 119, 662-674.

Wang, J., Liu, J., Wang, R., \& Wang, L. (2017). Experimental investigation on two solar-driven sorption-based devices to extract fresh water from atmosphere. Applied Thermal Engineering, 127, 1608-1616.

Wang, J., Wang, R., Wang, L., \& Liu, J. (2017). A high efficient semi-open system for fresh water production from atmosphere. Energy, 138, 542-551.

William, G. E., Mohamed, M., \& Fatouh, M. (2015). Desiccant system for water production from humid air using solar energy. Energy, 90, 1707-1720.

Zhao, F., Zhou, X., Liu, Y., Shi, Y., Dai, Y., \& Yu, G. (2019). Super moisture-absorbent gels for all-weather atmospheric water harvesting. Advanced Materials, 31(10), 1806446. 